\title{
THE PYTHAGOREAN INSGRIPTION ON ROSA'S LONDON 'SELF-PORTRAIT'
}

$\mathrm{T}$ he inscription on Salvator Rosa's 'selfportrait' in the National Gallery in London (Pl. 30) ${ }^{1}$ - Aut tace aut loquere meliora silentio' ('Either be silent or say something better than silence') - has rarely received extensive consideration in the literature on the painter. ${ }^{2}$ Yet an artist as attached to ancient themes as we know Rosa to have been, would surely have intended his motto to be taken not as a mere personal invention, but the expression of a classical way of thinking. The lack of scholarly attention given to Rosa's inscription probably stems from the fact that not only is it unrecorded in any of the contemporary emblem books or collections of proverbs, ${ }^{3}$ but there is also a complete absence of parallel or related sayings in classical Latin. ${ }^{4}$

Yet there is a clear Greek parallel unmentioned in any publication on Rosa, even though a note to this effect has for some time lain unnoticed in the files of the

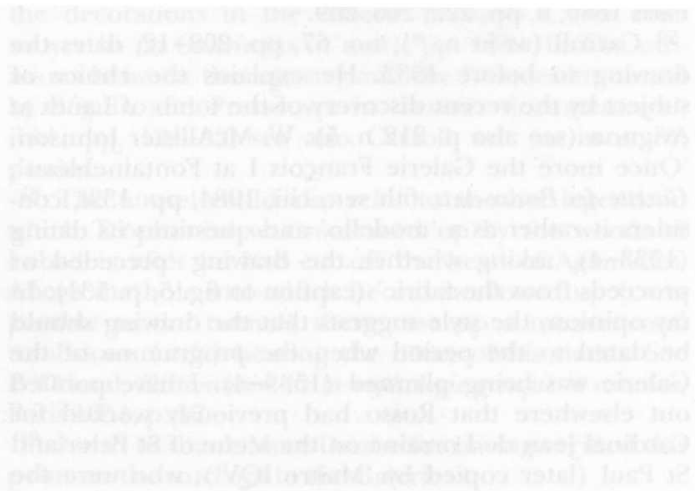

1 W. W. Roworth, in 'The Consolations of Friendship: Salvator Rosa's Self-Portrait for Giovanni Battista Ricciardi', Metropolitan Museum Journal, xxiii, 1988, pp. 103-24, has rightly argued against the proposal by Zeri and Meroni to identify as Giovanni Battista Ricciardi the man in Rosa's self-portrait in New York and in his highly probable self-portrait in London.

2 The best treatment so far is W. W. Roworth, 'Salvator Rosa's Self-Portraits: Some Problems of Identity and Meaning', The Seventeenth Century, iv, 1989, pp. 117-48, esp. 137-41. See also H. Langdon, 'Salvator Rosa in Florence', Apollo, cli, 1974, pp. 190-7, and W. W. Roworth, Pictor succensor. A Study of Salvator Rosa as Satirist, Cynic and Painter, London 1978, pp. 249-51. Roworth's reference to one of the sayings of Epictetus (no. 29), however, is unconvincing.

3 Roworth, 'Salvator Rosa's Self-Portraits' (as in n. 2 ), collected a number of contemporary and ancient sayings on different aspects of silence that she thought relevant to Rosa (cf. also n. 21 below). These are certainly not without interest, but none is a direct source for the London motto.

4 This was confirmed by a computerised search through the Thesaurus linguae latinae. 
National Gallery. ${ }^{5}$ Stobaeus writes (iii.34.7):

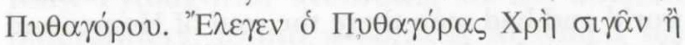

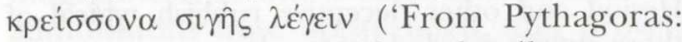
Pythagoras said one ought to be silent or say something better than silence'). ${ }^{6}$ The close connection with Rosa's motto is evident. The sole difference is the imperative of the London motto. A saying in this form, however, is to be found in Stobaeus seven lines

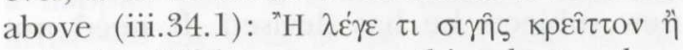

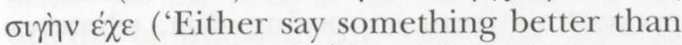
silence or be silent'). ${ }^{7}$ In philological terms, the London motto presents itself as a Latin fusion of the Pythagorean dictum, Stobaeus iii.34.7, and the 'inverted' version of Rosa's imperative, Stobaeus iii.34.1.

\footnotetext{
5 Having sent the National Gallery an account of the conclusions presented in this paper after completing the first draft, I was allowed access to the picture's dossier in the Gallery. I was surprised to discover a letter (dated 14 May 1976) from E. W. Playfair to Michael Levey, reporting a conversation with Arnaldo Momigliano. He writes: 'We were talking about those apparently classical tags which turn out to be products of the renaissance or later. [Momigliano] quoted as an example of the much rarer converse case the inscription on Salvator Rosa's portrait, which he had long thought to be composed ad hoc, but later to his surprise found to be a genuine classical piece: a Pythagorean dictum, he said, preserved only in Stobaeus; or rather a Latin translation of the Greek dictum in Stobaeus, probably by Carnerus [he means Canterus].' It was thus Momigliano who first discovered the Stobaeus parallel.

6 Quotations are based on C. Wachsmuth and O. Hense, Ioannis Stobaei anthologium, iii, Berlin 1894, p. 683 , i.12-14 (= iii.34.7), and p. 682, xi.8-9 (= iii.34.1).

7 The author's name is given: $\Delta$ tovvoiov, cf. Tragicorum Graecorum fragmenta, ii, ed. B. Snell, revised by R. Kannicht, Göttingen 1986, p. 244 (Dionysii fragmenta, no. 6). Stobaeus iii.34.7 is almost without parallel in Greek literature; cf. only Leutsch's Mantissa proverbiorum, 3.46 (Corpus paroemiographorum Graecorum [hereafter $C P G$ ], ed. E. von Leutsch, ii, Göttingen 1851, p. 779), and Gnomologium vaticanum, 459 (ed. L. Sternbach, Vienna $1887-9$, repr. Berlin 1963, p. 170), both of which name Pythagoras as the author of the dictum. The imperative iii.34.1 occurs slightly more often, but - as also in the case of iii.34.7 - in rather remote texts that we would do well to exclude as possible sources for Rosa: Menandri sententiae, 292 (ed. S. Jaekel, Leipzig 1964); Appendix proverbiorum, iii.7 (CPG, i, Göttingen 1839 , p. 416); Macarius, iv.44 (CPG, ii, p. 171); Gregorius Cyprius Codex Mosquensis, iii.61 (CPG, ii, p. 116); and Apostolius, viii.48 (CPG, ii, p. 444).
}

Above all the fact that Stobaeus names Pythagoras as the author gives this explanation a high degree of probability - a point I shall return to later. Of minor importance is a question that still remains unanswered: did Rosa know any Greek? ${ }^{8}$ The artist's distinguished circle of humanist friends in Florence could have easily helped him arrive at a knowledge of these sayings, and at the formulation adopted in his painting. Rosa's efforts, in letters, poems and works of art, to use Greek texts and to introduce Greek words and phrases, indicate how highly he valued the language ${ }^{9}$ and how much he wanted to be admired for his familiarity with it. At the same time there were available at this period a number of parallel (GreekLatin) editions and Latin translations of Stobaeus's Anthologia. ${ }^{10}$ None of these provides

8 Meroni, who for the sake of his argument about Ricciardi (cf. n. 1), must make the painter appear intellectually limited, categorically denies that Rosa could have known Greek: U. Meroni, 'Salvator Rosa: autoritratti e ritratti di amici', Prospettiva, xxv, 1981, pp. $65-70$.

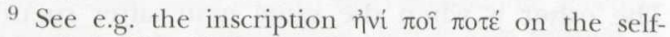
portrait in New York; also Rosa's letter to Ricciardi of 16 Sep. 1662 (G. A. Cesareo, Poesie e lettere di S. Rosa, Naples 1892, ii, p. 119): 'Lessi subito la vita d'Apollonio composta da Filostrato con mia particolar sodisfazione per quel che s'appartiene alla curiosità; ma non ci ho trovato quello, ch'ella mi significò, che ci averia trovato di singolare, e stravagante per la pittura, essendo fatti, che quasi tutti darebbono in una cosa medesima, onde ti prego a propormi qualch'altra cosa, acciò vi potessi trovar cose più fuori dell'ordinario, avendovi però notato alcuni fatti per servirmene.' Even small references in his correspondence show how Rosa aimed at Greek erudition: letter to Ricciardi, 4 June 1664 (Cesareo, op. cit., p. 123), 'Vi ricordi, che val più un solo verso d'Omero che un intero poema d'un Cherilo [= Choirilos]'. The question of the degree to which Rosa was acquainted with classical literature is beyond the scope of this paper. My examples have been chosen to indicate the impression of learning the artist hoped to make on his circle and on the public in general.

10 The following editions have been checked:

a) Othmar Luscinius (Nachtgal), Senarii graecanici quingenti et eo amplius versi, singuli moralem quandam sententiam aut typum proverbialem prae se ferentes, Strasbourg 1515, only Stobaeus iii.34.1: 'Aut prorsus taceas, aut sermonem ede silentio meliorem'- the translator has inverted the two halves of the sentence, thus presenting it in the form of Rosa's inscription! 
us with an exact model for Rosa's motto, but this does not argue against their relevance. The artist's talent in creating verbal variations is evident in his poetry and in many of the inscriptions to his prints.

Pythagoras himself features more than once in the works of Rosa. In his satire $L a$ musica he commends the ancient philosopher as a singer who (unlike those of his own day) encouraged youth to chastity:

Ma chi m'adita in questa nostra età
Un cantor che à Pittagora simile
La gioventtù riduca a castità?

Then there are the two paintings, executed as a pair in 1662: Pythagoras and the Fishermen (Berlin) and Pythagoras Emerging from the Underworld (Fort Worth). In the letter about these to his friend Ricciardi he seemed to affect at once pride in the originality of his subject-matter and a disparaging attitude towards their hero. As he puts it:

I have finished the two pictures I was working on, the subjects of which are entirely novel, never touched on before. I have painted on one canvas ...Pythagoras by the sea-shore surrounded by his sect, paying some fishermen for the net which they are pulling in, so as to set the fish free again, a theme taken from one of the essays of Plutarch. The other is when the same man, after spending a year living underground, at the end of it emerged, awaited by his sect, men and women

b) Apophthegmata ex variis auctoribus per Ioannem Stobaeum collecta Varino Camerte interprete, Rome 1517, repr. Cologne 1530 (Latin translation only, without Greek text): only Stobaeus iii.34.7, 'Pythagoras. oportet tacere vel silentio meliora dicere'.

c) Ioannis Stobei Sententiae ex thesauris Graecorum delectae, quarum auctores circiter ducentos $\mathcal{E}^{\circ}$ quinquaginta citat, $\mathcal{E}^{\circ}$ in sermones sive locos communes digestae, nunc primum a Conrado Gesnero Doctore Medico, Tigurino, in Latinum sermonem traductae, sicut Latina Graecis e regione respondeant, Basle 1543: Stobaeus iii.34.1, 'Aut dic aliquid silentio melius, aut sile' (as 'Euripidis'); and iii.34.7, 'Pythagoras dicebat, aut oportere silere, aut afferre meliora silentio'.

d) Michael Neander, Basle 1557, follows the translation of Gesner, as do most of the later editors (e.g. Canterus): Stobaeus iii.34.7, 'Pythagoras dicebat aut oportere silere, aut afferre meliora silentio'.

e) Dicta Poetarum quae apud Io. Stobaeum exstant. Emendata et latino carmine reddita ab Hugone Grotio, Paris 1623: Stobaeus iii.34.1, 'Silentio ni melius quid portas, tace' (as 'Incertus'; iii.34.7 is missing in this edition, which concentrates on the fragments of poets). alike, and said he had come from the Underworld and had seen there the soul of Homer and Hesiod and other deceptive rubbish typical of those simple-minded times... ${ }^{11}$

Yet the apparently dismissive phrase used to describe the claims of Pythagoras, 'coglionerie affettatorie', ${ }^{12}$ is perhaps only a rather crude attempt to compensate for the proud words in which Rosa has just described the new subjects he has devised. It need not prevent us from supposing that, whatever his view of the philosopher's precepts, he chose Pythagoras to exemplify the early 'golden age' of Stoic philosophy. He might in fact have wished to indicate the circumstances in which a sage like Pythagoras was able to teach in early Greece and southern

11 Letter to Ricciardi, 29 July 1662, in Cesareo (as in n. 9), ii, p. 118; also A. de Rinaldis, Lettere inedite di Salvator Rosa a G. B. Ricciardi, Rome 1963, p. 141, no. 107, whose transcription of the text runs: 'Ho concluso i due quadri, che stavo lavorando, i soggetti de'quali sono del tutto e per tutto nuovi, nè tocchi mai da nessuno. / Ho dipinto in una tela di palmi 8. per lo lungo Pitagora lungo la riva del mare cortegiato dalla sua Setta in atto di pagare ad alcuni pescatori una rete, che stanno tiranno $[=$ tirando $]$, a ciò si ridia la libertà a i pesci, motivo tolto da un opuscolo di Plutarco. / L'altro è quando il medesimo, dopo esser stato un anno sotteranea abitazione, alla fine d'esso, aspettato dalla sua Setta, così d'huomini, come di donne, uscì fuori e disse venir dagli Inferi, e d'haver veduto colà l'anima d'Homero, d'Esiodo, ed altre coglionerie appettatorie di quei tempi così dolcissimi di sale. Queste due opere l'ho fatte per esporle, alla fine di quest'altro mese, alla festa di S. Giovanni Deccollato: di quanto succederà, ne sarete puntualmente avisato.' On appettatorie see below, n. 12. For the paintings see H. Langdon in Salvator Rosa, exhib. cat., London 1973, pp. 33f, under no. 36 and pl. 37; Kimbell Art Museum. Catalogue of the Collection, Fort Worth, Texas 1972, pp. 76-80; and Roworth (Pictor succensor, as in n. 2), pp. 290-3, though her translation of the last passage is misleading (p. 292).

12 I have been unable to find a suitable translation for de Rinaldis's appettatorie - nothing in the Grande Dizionario della Lingua Italiana under appettare or appettato seems to make sense here. It has been proposed to me that the word should be taken as appestatorie, but Prof. Edgar Radtke of Heidelberg, who has kindly discussed the matter with me, considers this unlikely. Instead he suggested the reading appet[t]itorie, which would, however, yield a considerable change in meaning. Since I have had no opportunity to check the original text of the letter I have here, provisionally, adopted the old reading given in L. Ozzola, Vita e opere di Salvator Rosa, Strasbourg 1908, p. 140, even if this is not completely satisfactory. 
Italy. Pythagoras, according to his ancient biographers, found a context in which his admonitions were appreciated, and proved of 'natural' efficacy. This felicitous harmony between philosophical teachings and instinctive' obedience to those teachings on the part of the philosopher's followers may well have constituted for Rosa the notion of a happier past. It is not unlikely that the artist-in the wake of the Stoic view on the origins of philosophy ${ }^{13}$ _ saw this 'antiqua credulitas' (Seneca), ${ }^{14}$ the benevolent naivety with which people trusted and obeyed the early sapientes, as a positive trait of the epoch in which Pythagoras taught. For it was this naivety which, according to the doctrine of the Stoics, actually enabled men like Pythagoras to get their teachings across-in the case of Pythagoras by the use of his highly characteristic 'symbolic' method of instruction. ${ }^{15}$ These people were indeed 'dolcissimi

13 Cf. especially Seneca's letter xc.5-6: the reign of the sapientes was a natural one; their subjects accepted their admonitions and teachings because they were (quasi instinctively and through natural gift) aware of their correctness. For the free translation of Seneca's aetas aurea letter (xc) by Rosa's friend Evangelista Torricelli see Langdon (as in n. 2), pp. 190f.

14 Seneca, De constantia sapientis, ii.3: 'excussa iam antiqua credulitate', where he contrasts ancient simplicity and the cruelty of present times. It is a further case in point that Seneca uses the word 'credulitas' in his slightly ironical account of his own Pythagorean phase (Epistolae, cviii.21). He probably saw his enthusiastic Pythagorean beginnings as a first step towards Stoicism- not a false step, but a stage which had to be passed and left behind.

15 'Ergo brevis illa et compendiosa docendi ratio vocatur $\sigma u \mu \beta \lambda_{\mathrm{t}} \kappa \eta '$ ': O. Casel, De philosophorum graecorum silentio mystico, Giessen 1919, p. 58. Pythagoras's skill in 'dressing up wisdom [of the Egyptians]' (E. H. Gombrich, 'Icones symbolicae', in idem, Symbolic Images. Studies in the Art of the Renaissance, London 1972, p. 144) had the double function of making his message attractive and preventing it from profanation. 'Symbolic actions' such as those which Rosa chose for his Pythagorean paintings were likewise favoured by the Cynic school; $\mathrm{cf}$. the episode of Diogenes throwing away his cup, which Seneca expressly admired in his aetas aurea letter (Epistolae, xc; cf. above, n. 13) and which was painted and etched by Rosa (R. M. Wallace, The Etchings of Salvator Rosa, Princeton 1979, pp. 257-60, no. 103). Roworth (Pictor succensor, as in n. 2, p. 292) is perfectly right in stressing the cynic qualities of Rosa's Pythagoras. It may be noted that the Latin inscription on Rosa's Diogenes print exhibits a characteristically di sale', but it was precisely this unspoilt disposition that ensured the effectiveness of Pythagorean philosophy. Rosa's motive for painting the two works might thus be closer to classical thought than first impressions would indicate.

Even if Rosa's comments are taken as essentially negative, the words of someone who looks at Pythagoras as an entertaining (not to say ridiculous) figure, ${ }^{16}$ it should be remembered that certain aspects of the Pythagorean 'way of life' already aroused irritation in antiquity. Seneca's mildly ironical account of reactions to his Pythagorean vegetarianism is a famous example. ${ }^{17}$ Thus, the attitude of amused distance to Pythagoras itself has a classical tradition.

Rosa also mentions the custom among Pythagoras's pupils of remaining in absolute silence for three to five years. He does so in a way that shows he was well acquainted with this habit. ${ }^{18}$ The rule of silence in the school of Pythagoras is indeed well-attested and seems to have been almost proverbial. ${ }^{19}$ But

independent choice of words which appears to have no close parallel in the ancient sources about the anecdote (available in G. Giannantoni, Socraticorum reliquiae, ii, Rome 1983, nos 156-62, 175, 191, 298, 536, 543). This inscription too reflects a search for originality.

16 This is the position of the catalogue entry for a second version of 'Pythagoras and the Fishermen' in the Kunsthaus Zürich: see C. Klemm, Die Gemälde der Stiftung Betty und David M. Koetser, Zurich 1988, p. 124.

17 Cf. Seneca, Epistolae, cviii.22. It is revealing to find that certain passages in which Rosa criticises or mocks particular customs of classical antiquity have close parallels, of similar intention, in ancient philosophical writings. For example, Rosa's 'Era Dea sin la febre, e a' suoi pericoli / Si facean sacrificij' (L'Invidia, 177f, in Cesareo, as in n. 9, i, p. 291), looks very much like Epic-

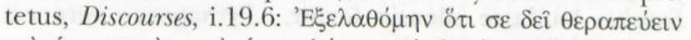

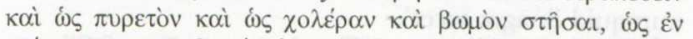

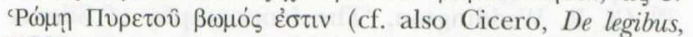
ii.28).

18 'Vi diedi Aviso della Comparsa del sig.r Ugo, nè da quel hora in qua hò ha[v]uto mai più nuova di Voi: che Domine sarà con tanto silentio? Che volete forse farvi Scolare di Pitaghora? Ma parliamo d'altro': letter to Ricciardi, 28 Oct. 1651 (Cesareo, as in n. 9, ii, p. 88); already mentioned without precise reference in Langdon (as in n. 2), p. 190.

19 A list with quotations from antiquity and the Renaissance is provided in E. Wind, Pagan Mysteries in the Renaissance, Oxford 1980, p. 53 n. 4. To this can be added Seneca's letters lii.10 and xc.6; Clement of 
this most famous of silences belongs within the wider complex of philosophical or

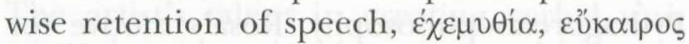
$\sigma \iota \eta^{20}$ — about which Rosa says:

Il silenzio in un uomo è una virtù, la più loquace che possi decantar le sue glorie. ${ }^{21}$

It is within this context that we should seek to understand Rosa's motivation in using the Pythagorean saying. Because he naturally could not expect the ordinary viewer to identify the motto of his picture as a very precise reference to a specific classical source, Rosa presented more than one way of reading the painting (and likewise its companion-piece in Hartford). First-but not foremost-it functions as a self-portrait, while the Hartford picture represents his mistress Lucrezia. This aspect, however, was

Alexandria, Stromata, v.11.1; and Apuleius, Florida, 15, which is worth quoting here: 'Nihil prius discipulos suos docuit [sc. Pythagoras] quam tacere, primaque apud eum meditatio sapienti futuro linguam omnem coercere, verbaque, quae volantia poetae appellant, ea verba detractis pinnis intra murum candentium dentium premere. Prorsus, inquam, hoc erat primum sapientiae rudimentum, meditari condiscere, loquitari dediscere'. The two poetical descriptions of pictures representing Pythagoras in the Anthologia graeca (xvi. 325 and 326) have already been noted by Wind, as well as Lessing's paraphrase ('Warum dies Bild nicht spricht? Es ist Pythagoras'). On Pythagorean silence cf. also W. Burkert, Weisheit und Wissenschaft. Studien zu Pythagoras, Philolaos und Platon, Nuremberg 1962, pp. 162f. The Pythagoras madrigals of Marino are briefly discussed by M. Albrecht-Bott, Die bildende Kunst in der italienischen Lyrik der Renaissance und des Barock, Wiesbaden 1976, p. 82. The inscription of René Boyvin's 'Pythagoras' (A. Robert-Dumesnil, Le peintre-graveur français, viii, Paris 1850 , p. 55 , no. 92) is 'Pythagoras Samius laudasse silentia fertur, / Pythagorae vera est numquid imago: tacet'.

20 Cf. R. Waddington, 'The Iconography of Silence and Chapman's Hercules', this Journal, xxxiii, 1970, pp. 248-63. There is a bibliography on all aspects of 'silence' in U. Schmitz (ed.), 'Schweigen', Osnabrücker Beiträge zur Sprachtheorie, xlii, 1990, pp. 43-58.

21 Salvator Rosa, Il teatro della politica. Sentenziosi afforismi della prudenza, ed. G. Baroni, Bologna 1991, p. 98, no. 822 ( $\mathrm{I}$ am indebted to Jonathan Scott for this reference). Roworth, 'Salvator Rosa's Self-Portraits' (as in n. 2), p. 140 (cf. her n. 42), quotes further antique sayings connected with silence from the painter's notebook (this notebook was still unpublished when she wrote her article). probably incidental for Rosa: he and Lucrezia simply provided the most easily available subjects. ${ }^{22}$ Of greater importance is the concept of philosophical silence which the beholder could recognise, without necessarily understanding all its implications. Presenting the typical appearance of a painted Seicento philosopher, Rosa poses as the representative of philosophy while, as was recognised long ago, ${ }^{23}$ Lucrezia embodies Poetry. An attentive viewer could go a little further: connecting 'philosophical silence' with 'Pythagoras' such a viewer might have recalled classical references to Pythagoras as the inventor of the word 'philosophy'. ${ }^{24}$ A select few, the 'experts', would have connected the picture's motto with the saying from Stobaeus. Rosa's quotation qua quotation was thus perhaps nothing but a personal message to a friend.

The complicated process by which a Greek saying turned into a Latin inscription for a picture has, as far as I am aware, no parallel in the period. ${ }^{25}$ Even in Rosa's other

22 Cf. Roworth, 'Salvator Rosa's Self-Portraits' (as in n. 2), p. 118: 'While the National Gallery painting may incorporate the artist's idealised features, it must primarily be understood as an allegorical figure'. E. T. A. Hoffmann grasped Rosa's 'method' very precisely: 'Man merkt es, daß Ihr selbst Euer reges lebendiges Modell seid, indem Ihr, wann Ihr zeichnet oder malt, vor einem großen Spiegel die Figur darstellt, die Ihr auf die Leinwand zu bringen im Sinne habt!'-'Der Tausend! Antonio', rief Salvator lachend, 'ich glaube, Ihr habt schon öfters, ohne daß ich es eben gewahr worden, in meine Werkstatt gekuckt, da Ihr so genau wisset, wie es darin hergeht?' (E. T. A. Hoffmann, Signor Formica, pp. $778 \mathrm{f}$ of his novel Die Serapionsbrüder, edn Munich 1976).

23 For the most recent survey of the picture's history and that of its companion-piece cf. J. K. Cadogan, Wadsworth Atheneum Paintings, II: Italy and Spain, Hartford 1991, pp. 213-16.

24 Cf. Cicero, Tusculanae disputationes, v.8-10 (Heraclides is named as the source; cf. H. B. Gottschalk, Heraclides of Pontus, Oxford 1980, pp. 29-31); Diogenes Laertius, Vitae, i.12; Isidore, Origenes, xiv.6.31.

25 I have identified one case in the Cinquecento of the use of painted mottoes which were taken from Stobaeus's Anthologia. We find them on the tablets held by two Greek celebrities on the ceiling of Zuccaro's 'Stanza della solitudine' at Caprarola. Annibale Caro's 
Latin inscriptions there seems to be nothing more than-at best-a certain eclecticism

concetto for this room (A. Caro, Lettere familiari, ed. A. Greco, i, Florence 1957, p. 239) gives to Euripides the motto 'Qui agit plurima, plurimum peccat'. The Greek original is preserved only in Stobaeus (Anthologia,

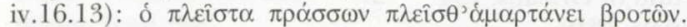
The tavola of Menander, 'Virtutis et liberae vitae magistra optima solitudo', is also, in a remarkably free translation, derived from Stobaeus (Anthologia, iv.15.5-the preceding chapter!): 'А '๋'

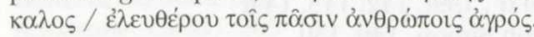

in the use of ancient sources. But perhaps this case will lead to further explorations and further discoveries.

ECKHARD LEUSCHNER 